\title{
Havza Yönetiminde Bölgesel Elektrik Ticareti Modeli: Aral ve Kura-Aras Havzaları Üzerine Bir Değerlendirme*
} Halil Burak Sakal ${ }^{\star *}$

\begin{abstract}
öz
Dünyanın birçok bölgesinde problemli alanların başında gelen sınıraşan nehir havzalarının yönetimi konusu, Sovyet Sosyalist Cumhuriyetler Birliği'nin (SSCB) yıkılmasının ardından Merkezî Asya'da da bölgesel siyasetin önemli gündem maddeleri arasında yer almıştır. Bu sorun alanı, Aral Gölü felaketinin belirginleşmeye başladığı yıllardan itibaren uluslararası çevresel ve siyasî tartışmaların merkezinde yer bulmaya başlamıştır. KuraAras havzasını ilgilendiren çevresel ve bölgesel siyasetle alakalı konular ise Aral havzasıyla ilgili tartışmalar kadar literatürde ve uluslararası siyasetin gündeminde yer bulamamıştır. Bu makale, Türk dünyasını içine alan bu önemli ve geniş nehir havzaları temelinde sınıraşan su sistemlerini ilgilendiren temel sorun alanlarını bölgesel bütünleşme kuramları çerçevesinde karşılaştırılmalı olarak ele almakta ve bunlara iktisadî yaklaşımı ve bölgesel elektrik enerjisi ticaretini temel alan çözüm önerileri sunmaktadır.
\end{abstract}

\section{Anahtar Kelimeler}

Merkezî Asya, Kafkasya, Aral havzası, Kura-Aras havzası, sınıraşan sular, çevre.

\footnotetext{
Geliş Tarihi: 08 Ağustos 2018 - Kabul Tarihi: 30 Ocak 2019 Bu makaleyi şu șekilde kaynak gösterebilirsiniz:

Sakal, Halil Burak (2020). "Havza Yönetiminde Bölgesel Elektrik Ticareti Modeli: Aral ve Kura-Aras Havzaları Üzerine Bir Değerlendirme”. bilig - Türk Dünyası Sosyal Bilimler Dergisi 95: 241-270.

" Dr. Öğretim Üyesi, Kapadokya Üniversitesi, İ̈BF, Siyaset Bilimi ve Uluslararası İlişkiler Bölümü Nevşehir/Türkiye ORCID ID: 0000-0002-2054-5222 burak.sakal@kapadokya.edu.tr
} 


\section{Giriş}

Merkezî Asya ${ }^{1}$ ve Güney Kafkasya’nın en geniş nehir havzaları olan Aral ve Kura-Aras havzalarında su yönetimi, kaçınılmaz olarak yirminci yüzyılda yaşanan siyasî ve iktisadî gelişmelerden etkilenmiştir. Sovyet Sosyalist Cumhuriyetler Birliği'nin (SSCB) dağılmasının ardından Aral havzası, bölgesel sınıraşan su meselelerinin ve Aral Gölü felaketi nedeniyle çevre problemlerinin önde gelen konuları arasında yer almıştır. Kura-Aras havzası ise 1990'lı yıllar itibariyle çevre meseleleri başta olmak üzere birçok sorunla karşılaşmıştır. Havzaların yer aldığı Merkezî Asya ve Kafkasya bölgelerinin su ve enerji komplekslerini birbirine bağlayan ortak alan, Hazar Denizi'dir. Günümüzde Rusya’nın Hazar siyasetindeki ağırlığı göz önünde bulundurulduğunda, Tanrısever'in (2015) belirttiği gibi, havzaları ilgilendiren çevre ve enerji konularındaki gelişmelerde Rusya faktörünü dikkate almak önemlidir. Görülmektedir ki, su kaynaklarının yönetimiyle ilgili sorunların siyasî temelleri, bu konuların tahlilinde teknik yaklaşımların yanında siyasî ve iktisadî yaklaşımların önemini artırmıştır (Mollinga 2008). Bu bağlamda bu makale, havzaların sorunlarını siyasî ve iktisadî temelde değerlendirmektedir.

Aral ve Kura-Aras havzaları örneklerinde, iktisat temelli bütünleşme ve bölgesel elektrik şebekelerinin faydalarına odaklanan kuramsal yaklaşımları esas alan bu makale, Balassa’nın (1961) güdümcü olarak nitelediği, devletler düzeyinde işleyen ve elektrik enerjisinin diğer mal ve hizmetlerde olduğu gibi taşıma maliyeti kaynaklı engellere takılmaksızın (Kindleberger 1963: 190-192) aktarılmasını esas alan "iktisadî-teknik" bütünleşme çerçevesine oturtulmuştur. Bunun yanında, ülkeler arası elektrik bağlantılarının gelişmesinin ve ortak elektrik enerjisi piyasasının güçlendirilmesinin faydalarına odaklanan kuramsal yaklaşımlar (Turvey 2006, Pineau vd. 2004, Pineau 2012, Baritaud vd. 2014) ${ }^{2}$ bu makalede söz konusu havza örnekleriyle ele alınmıştır. Bu bağlamda bu makalenin amacı, Merkezî Asya ve Güney Kafkasya'yı konu alan bölgesel ve ticaret temelli bütünleşme tartışmalarına, Aral ve Kura-Aras havzalarını kapsayan elektrik enerjisi ticareti yaklaşımıyla katkıda bulunmaktır. 


\section{Bölgesel İş Birliğine Elektrik Ticareti Yaklaşımı}

İkinci Dünya Savaşı'ndan sonra Avrupa ve Kuzey Amerika eksenli tartışılan bölgesel bütünleşme (Viner 1950, Meade 1955, Haas 1961, Kindleberger 1963) konusu, 1960 'lı ve 1970 'li yıllarda gelişmekte olan ülkeler arasındaki bölgesel ticaret ilişkilerini kapsayacak şekilde genişlemiştir (Lipsey 1960, Balassa 1961, Balassa 1965, Bhambri 1962, Balassa vd. 1975, Balassa 1994). ${ }^{3}$ SSCB'nin dağılmasının ardından ise Merkezî Asya ve Güney Kafkasyàda bağımsızlıklarını elde eden ülkeler, bölgesel bütünleşme literatürüne dâhil olmaya başlamışlardır. Bu kapsamda bu bölgeler özelinde hem siyasî hem de iktisadî bütünleşme ve iş birliği yaklaşımları gündeme gelmiştir.

Bağımsızlığı takip eden on yılda Merkezî Asya liderlerinin siyasî bütünleşmeye yönelik bazı çabaları (Karasar vd. 2009) görülse de 2000’li yıllara gelindiğinde bölgesel siyasî rekabetin etkisiyle entegrasyon eğilimi zayıflamıştır (Spechler 2002, Pomfret 2009). Bağımsızlıktan sonra kurulan bölgesel örgütlerin yeterli entegrasyonu sağlayamadığ1 görülmektedir (Rakhimov 2010, Libman vd. 2011). Güney Kafkasya bölgesinde entegrasyon çabalarıyla ilgili tartışmalar ise (Mankoff 2012), Çin (Ögütçü 2015) ABD (Elma 2014, Chiragov vd. 2015) ve Türkiye'nin (Veliyev 2015) bütünleşme üzerine etkilerinin yanında, ulaştırma altyapısı (Gasimli 2015), Avrupa Birliği (AB) ve Kuzey Atlantik Anlaşması Örgütü (NATO) gibi kuruluşların rolleri (Kakachia 2015, Paul 2015, Shiriyev 2015) veya bütünleşme çabalarının önündeki engeller (Pashayeva 2015, Ahmadli 2017) bağlamında yürütülmektedir.

Merkezî Asya ve Güney Kafkasya’da iktisat ve ticaret temelli bütünleşme yaklaşımları (McPherson 2014, Opitz 2015, Aynagöz Çakmak 2017) ile enerji ticaretini esas alan bütünleşme tartışmaları (Bohr 2004, Kakhkharov 2007) literatürde yer bulmaktadır. Bu bölgelerin en önemli su kaynakları olan Aral ve Kura-Aras havzalarında su yönetimi sorunlarının çözümü için ise havza ülkelerinin tamamının iş birliği içinde olmaları önemlidir. $\mathrm{Bu}$ makalede önerildiği üzere, bu iş birliğinin temeli olarak, bölgesel hidroelektrik ticareti modeli esas alınabilir.

Ülkeler arası elektrik enerjisi ticareti iktisadî ve teknik bir konudur. 
Dünyada birbirine coğrafi olarak yakın birçok ülke arasında çeşitli seviyelerde elektrik enerjisi ticareti gerçekleşmektedir. Bu elektrik ticareti, uluslararası anlaşmaların sağladığı hukuki zemin, ülkeler arasındaki ticari ilişkileri geliştirme yönündeki siyasî irade ve sınır ötesi elektrik naklini sağlayabilecek teknik altyapılar sayesinde mümkün olabilmektedir. Ülkeler arası elektrik şebekelerinin bütünleşmesinin teknik ve ekonomik açıdan faydaları bulunmaktadır (Pierce vd. 2006, Turvey 2006, Pineau 2012, Baritaud vd. 2014) ve dünyada iktisadî açıdan gelişmiş birçok bölgede, bu entegrasyon sağlanmış durumdadır. Üretim maliyetlerini düşürme, enerji kaynaklarının etkin kullanımı, arz güvenliğinin sağlanması, entegrasyonun faydaları arasındadır (Pierce vd. 2006: 2-7). Bu faydalar, birbirleriyle elektrik ticareti yapan bölgelerde birbirinden farklı elektrik üretim kaynaklarının mevcudiyeti halinde yükselmektedir (Pineau vd. 2004: 1459-1460). Aral ve Kura-Aras havzalarındaki ülkelerde farklı elektrik üretim kaynaklarının bulunması, bu havzalarda elektrik ticaretinin avantajlarını artırmaktadır. Teknik ve iktisadî alanlarda mevcut olan bu avantajlar, havzalarda bölgesel elektrik ticaretini teşvik edebilecek unsurlardır. Bu bağlamda, söz konusu bölgelerde entegrasyonun sağlanması, nehir havzası temelli su yönetimi sorunlarına ortak çözüm getirilmesi bakımından önemlidir.

Takip eden iki bölümde, öncelikle Aral ve Kura-Aras havzalarının genel fiziksel özellikleri özetlenmekte, daha sonra ise bölgesel elektrik ticareti modeliyle çözüme kavuşturulması önerilen sorun alanları üzerinde durulmaktadır.

\section{Aral ve Kura-Aras Havzalarının Genel Özellikleri}

Aral havzasının büyük nehri Ceyhun (Amuderya), Afganistan'daki Vrevsk Buzulu'ndan kaynağını alır ve Tacikistan'da Vahş Nehri ile birleştikten sonra Amuderya adıyla Aral Gölü’ ne kadar akışını sürdürür (Zonn vd. 2009: 13). Seyhun (Sirderya) ise Tanrı Dağları'nın kuzeyinden kaynağını alan Narın ile Karadarya’nın birleşmesiyle oluşur (Şekil 1). Seyhun'un birçok büyük kolu sulama kanallarına yönlendirildiğinden nehre ulaşamamaktadır (Zonn vd. 2009: 211-212). 


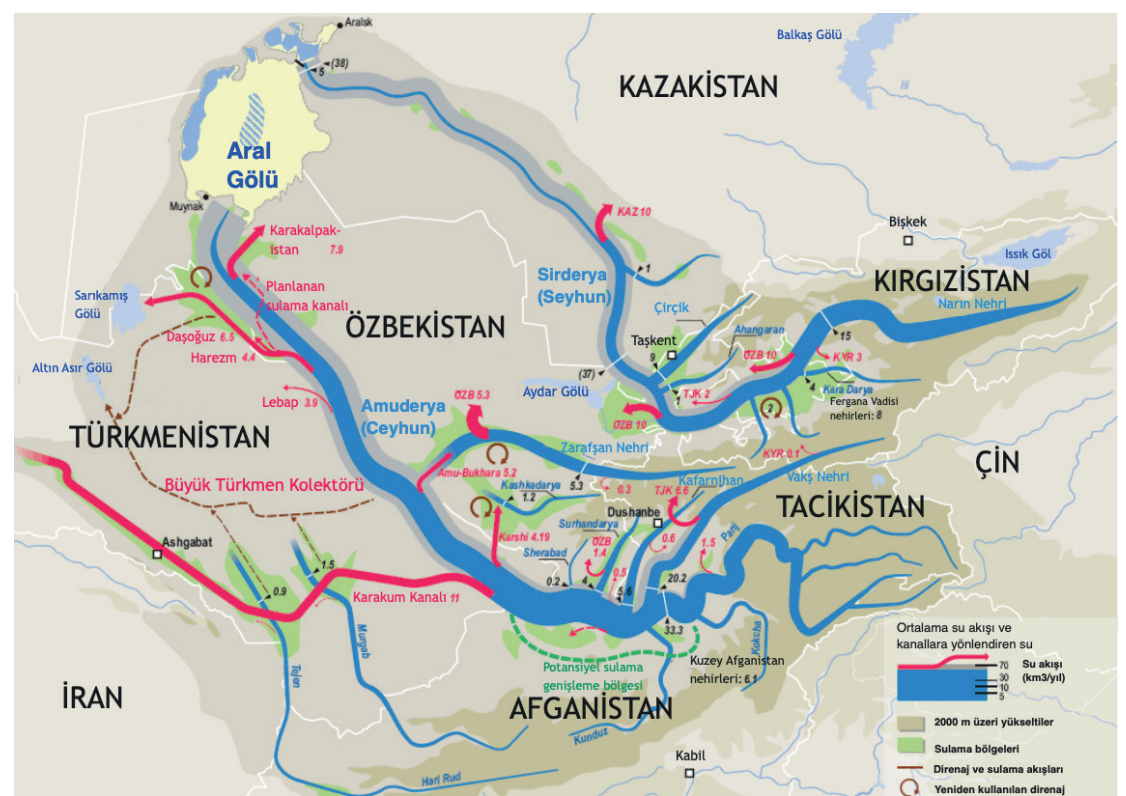

Şekil 1. Aral havzasının şematik haritası (CA Water 2018).

SSCB'nin su politikaları neticesinde hacminin çoğunluğunu yitirmiş olan Aral Gölü̉nün sorunlarının çözümüne yönelik girişimler, son yirmi yılda artmıştır. Bölgesel ve küresel çabalarla son yıllarda Aral Gölü’nün su hacmindeki azalma kısmen geri çevrilmiş olsa da (World Bank 2001, Bland 2015, ESA 2018) gölün neredeyse tamamen kuruması önemli çevre sorunlarına yol açmaktadır (Columbia University 2008). ${ }^{4}$ Bölgede Aral ile ilgili çalışmalar 1992 yılında kurulan Aral Gölü’nü Kurtarma Uluslararası Fonu'nun çabalarıyla devam etmektedir. Ağustos 2018'de devlet başkanları düzeyinde gerçekleşen fonun son toplantısında bölgesel ve küresel (Birleşmiş Milletler 2018) iş birliğinin önemi vurgulanmıştır (Türkmenistan Dışişleri Bakanlığı 2018).

Kura-Aras havzası, Güney Kafkasya’da yer alan bir kapalı havzadır. Türkiye, Gürcistan ve İran'ın bir kısmı, Ermenistan'ın tamamı, Azerbaycan'ın yaklaşık yüzde 70'i havzanın sınırları dâhilindedir (FAO 2009). Kura ve Aras nehirleri kaynağını Türkiye'den alır, iki nehir Azerbaycan topraklarında birleşir, Hazar Denizi’ne dökülür (Şekil 2). Havzayla ilgili akademik çalışmalar Gürcistan, Ermenistan ve Azerbaycan üzerine yoğunlaşmaktadır (Barabadze 2003, Ewing 2003, Ubilava 2004, Vener 2006, Campana vd. 
2008, Vener vd. 2009, Campana vd. 2012, Leummens vd. 2013). Bu makale, mevcut literatürden farklı olarak, Türkiye ve İran'ı da içine alan havza temelli bir yaklaşım önermektedir.

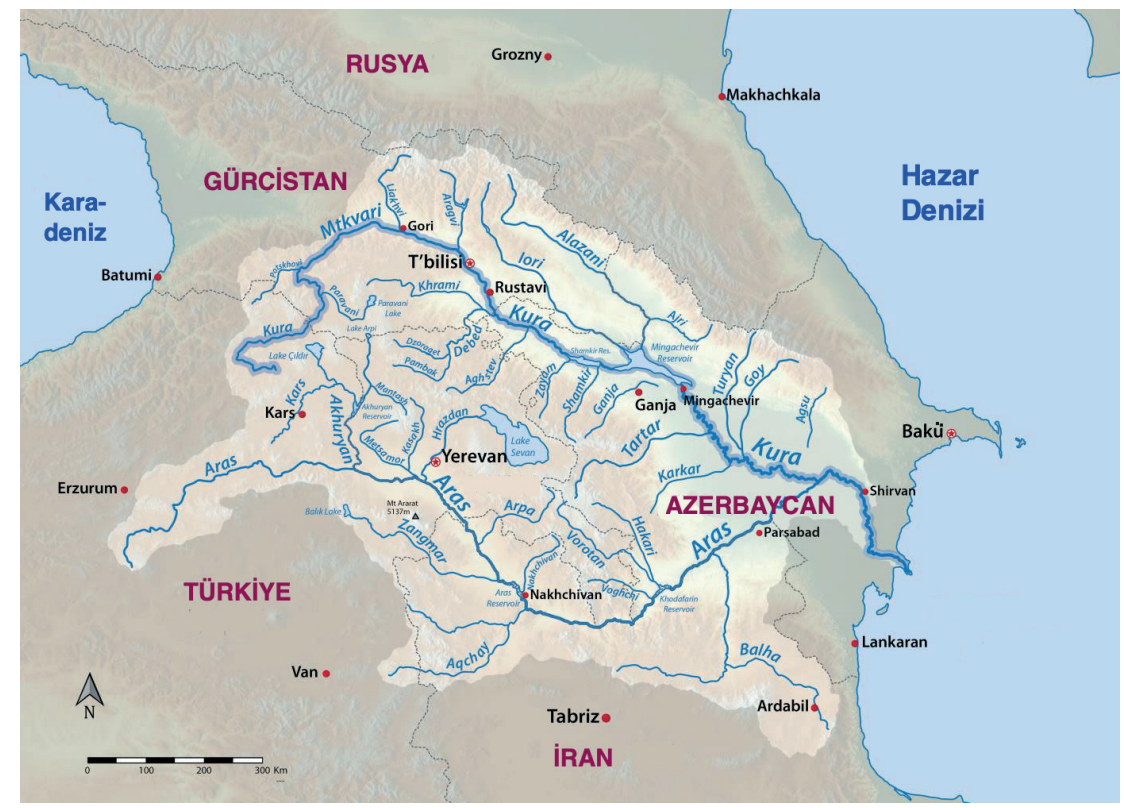

Şekil 2. Kura-Aras havzasının haritası (EU Water Initiative for Eastern Partnership 2018).

\section{Havzalarda Su Yönetimi ve Temel Sorun Alanları}

Aral ile Kura-Aras havzalarının benzer ve farklı sorun alanları bulunmaktadır. Bu bölümde bu havzaların su yönetimi ve enerjiyle ilgili temel sorun alanları karşılaştırmalı olarak incelenecektir. Daha sonra elektrik ticareti temelli bölgesel iş birliği modellerinden hareketle çözüm önerileri sunulacaktır.

\section{Aral havzası}

Aral havzasında çarlık ve Sovyet hükûmetlerinin su politikaları (Michael 1938: 3), sulanan tarım arazilerini sürekli olarak artırmıştır (Craumer 1992: 132-133). Merkezî Asya'da 2000'li yıllara gelindiğinde sulanan arazilerin toplamı yaklaşık 8 milyon hektarı bulmuş; Seyhun Nehri'nin akışının yüzde 78 'ine yakını, Ceyhun'un neredeyse yüzde 94'ü inşa edilen su yapılarıyla düzenlenmiştir (Rakhmatullaev vd. 2010: 310 ve 315). Bu yoğunlukta yürütülen sulu tarım faaliyeti, bölgenin sınırlı olan su kaynaklarıyla ilgili 
bir su paylaşımı meselesini beraberinde getirmiştir. Bu meselenin en önemli parçası tarımsal sulamadan üst düzey fayda sağlayan Özbekistan'ın, memba ülkelerden topraklarına gelen tatlı su kaynaklarına yüksek bağımlılığıdır (Abdolvand vd. 2015: 902-903, FAO 2016, Agayeva 2017) (Tablo 1).

Tablo 1. Bazı Önemli Su Verileri

\begin{tabular}{|c|c|c|c|c|c|c|c|c|c|c|}
\hline & \multicolumn{5}{|c|}{ Kura-Aras Havzası } & \multicolumn{5}{|c|}{ Aral Havzası } \\
\hline & ERM & AZE & GÜR & İRAN & TR & KAZ & KIR & TAC & TÜR & ÖZB \\
\hline $\begin{array}{l}\text { Toplam yurt } \\
\text { içi yenilenebilir } \\
\text { su kaynakları } \\
\text { (milyar metre- } \\
\text { küp/yıl) }\end{array}$ & 6,859 & 8,115 & 58,13 & 128,5 & 227 & 64,35 & 48,93 & 63,46 & 1,405 & 16,34 \\
\hline $\begin{array}{l}\text { Fert başı top- } \\
\text { lam yurt içi } \\
\text { yenilenebilir } \\
\text { su kaynakları } \\
\text { (metreküp/fert/ } \\
\text { yıl) }\end{array}$ & 2273 & 832 & 14532 & 1624 & 2886 & 3651 & 8237 & 7482 & 261,4 & 546,6 \\
\hline $\begin{array}{l}\text { Fert başı top- } \\
\text { lam su tüketimi } \\
\text { (metreküp/fert/ } \\
\text { y1l) }\end{array}$ & 956,5 & 1393 & 413,4 & 1301 & 576,9 & 1315 & 1531 & 1619 & 5753 & 2106 \\
\hline $\begin{array}{l}\text { Bağımlılık } \\
\text { oranı } \\
\text { (yüzde) } \\
\end{array}$ & 11,71 & 76,6 & 8,211 & 6,773 & 1,518 & 40,64 & 1,128 & 17,34 & 97 & 80,07 \\
\hline $\begin{array}{l}\text { Tarımsal su } \\
\text { tüketimi } \\
\text { (milyar metre- } \\
\text { küp/yıl) }\end{array}$ & 1,89 & 9,33 & 1,055 & 86 & 29,6 & 14,03 & 7,447 & 10,44 & 26,36 & 50,4 \\
\hline $\begin{array}{l}\text { Su stresi } \\
\text { (yüzde) }\end{array}$ & 57,67 & 54,19 & 4,548 & 90 & 26,24 & 27,92 & 43,95 & 71,36 & 162,8 & 138,8 \\
\hline$V_{V}$ & & & & & & & & & & \\
\hline $\begin{array}{l}\text { Merkezî Asya } \\
\text { örgütlerin gi } \\
\text { Merkezî Asya } \\
\text { ortak kararıyl } \\
\text { yer almaktadı } \\
\text { yanında (UN }\end{array}$ & $\begin{array}{l}\text { a'daki } \\
\text { irişimle } \\
\text { a ülkel } \\
\text { la kuru } \\
\text { lir. Birl }\end{array}$ & $\begin{array}{l}\text { su ve } \\
\text { eri ön } \\
\text { leri, AF } \\
\text { ulan } \mathrm{N}\end{array}$ & $\begin{array}{l}\text { çevre } \\
\text { nemlid } \\
B \text { ve } \\
\text { Merkez } \\
\text { Mille }\end{array}$ & $\begin{array}{l}\text { e sorun } \\
\text { dir. Bu } \\
\text { Birleşm } \\
\text { zî Asya }\end{array}$ & $\begin{array}{l}\text { nlarına } \\
\text { unlar } \\
\text { niş Mil } \\
\text { Bölge } \\
\text { (BM) }\end{array}$ & $\begin{array}{l}\text { a yön } \\
\text { arasın } \\
\text { illetler } \\
\text { resel Ç }\end{array}$ & $\begin{array}{l}\text { helik k } \\
\text { nda } 2 \\
\text { r Kalk } \\
\text { Çevre } \\
\text { gede y } \\
\text { Banka }\end{array}$ & $\begin{array}{l}\text { küresel } \\
2001 \\
\text { kinma } \\
\text { Merke } \\
\text { Mï̈t+̈̈ }\end{array}$ & $\begin{array}{l}\text { ve bö } \\
\text { yilında } \\
\text { Prograi }\end{array}$ & $\begin{array}{r}\text { ölgesel } \\
\text { tüm } \\
\text { amının } \\
\text { AREC) }\end{array}$ \\
\hline
\end{tabular}


Bankası, Avrasya Kalkınma Bankası, Avrupa İmar ve Kalkınma Bankası gibi kuruluşlar bölgede sürdürülebilir kalkınma için desteklerini sürdürmektedir (UNDP 2014). Bu çalışmalar sayesinde son dönemde bölgesel su ve çevre problemlerinin çözümüne yönelik kısmî gelişmeler kaydedilmiştir. Örneğin Haziran 2018'de Taşkent'te BM, AB, Dünya Bankası gibi kuruluşların desteği ile gerçekleşen Merkezî Asya Uluslararası Çevre Forumu'nda Özbek yetkililerce Aral havzası su kaynaklarının kullanımına ilişkin BM Sözleşmesi'nin hazırlanmasının hızlandırılması çağrısında bulunulmuştur (CAREC 2018). Bu forum, Özbekistan meclisinin iklim değişikliğine ilişkin Paris Anlaşması'nı Eylül 2018'de onaylamasından hemen önce gerçekleşmiştir (The Tashkent Times 2018). Tüm bu çabalar olumlu olmakla birlikte yeterli değildir.

Özbekistan ve Türkmenistan gibi ülkelerin tarım ve su kaynakları açısından memba ülkelere yüksek bağımlılığı, su yönetimi alanında bölgesel iş birliğini gerekli kılmaktadır. Ancak, daha önce değinildiği üzere, bağımsızlıktan sonraki yıllarda Merkezî Asya ülkelerinin izlediği su politikaları (Veldwisch 2008, Arsel vd. 2010, Bichsel vd. 2010) bölgesel su yönetimi bağlamında kapsamlı iş birliğini sağlayacak bir ortam oluşturmamıştır. Bölgede tesis edilecek elektrik enerjisi entegrasyonu ülkeler arası iş birliğini sağlayabilir. $\mathrm{Bu}$ entegrasyonun teknik ve hukuki altyapısı mevcuttur.

Entegrasyonun teknik altyapısı SSCB zamanında oluşturulmuştur. Bu dönemde, Sovyet cumhuriyetleri arasında kurulan su-enerji takasi sistemi, su kaynakları açısından zengin memba ülkelerin (Kırgızistan ve Tacikistan) mansap ülkelere (Özbekistan, Türkmenistan ve Kazakistan) sulama mevsiminde rezervuarlarından su salımını, kışın ise rezervuarlarda suyun tutulmasını içermekteydi (O’Hara 2000: 438-439). Ancak bu durum kış mevsiminde enerjiye ihtiyaç duyan memba ülkelerde hidroelektrik enerji üretimini kısıtlıyordu. Bu sorunun çözümüyse, Özbekistan'daki termik santrallerin kış mevsiminde yüksek verimle çalıştırılması ve üretilen elektrik enerjisinin artan kısmının Merkezî Asya Güç Sistemi (MAGS) ${ }^{5}$ aracılığıyla memba ülkelere iletilmesi yoluyla bulunmuştu. Sovyet döneminde etkin olarak çalışan (Wegerich vd. 2007, Wegerich 2008, Kayumov 2012, Stucki vd 2014, Granit vd. 2014) bu sistem, bağımsızlığı izleyen on y1l içinde işlemez hale gelmiştir (Wooden 2014: 471).

Bölge ülkeleri arasında havza yönetimi alanında iş birliğini öngören 
kapsamlı hukuki düzenlemeler bulunmaktadır. Örneğin 1992'de imzalanan suyun eşit paylaşımı ilkesine dayalı anlaşmayla ${ }^{6}$ Devletlerarası $\mathrm{Su}$ Koordinasyon Komisyonu ve bu yapıya bağlı olarak faaliyet gösterecek Seyhun ve Ceyhun havza su birlikleri ${ }^{7}$ kurulmuştur. Su idaresinin havza su birliklerine devri, bağımsızlıktan sonraki yıllarda su yönetimi alanındaki kapsamlı değişikliklerden biri olarak görülmektedir (Veldwisch vd. 2008, Veldwisch vd. 2013). Bundan kısa süre sonra, 1998, 1999 ve 2000 yıllarında Kazakistan, Kırgızistan ve Özbekistan arasında imzalanan bir dizi anlaşmayla Seyhun ve Ceyhun üzerindeki rezervuarlardan su salımı, elektrik üretimi ve iletimi konuları düzenlenmiştir. Bu anlaşmalar bir anlamda, yukarıda bahsedilen, Sovyet dönemindeki su-enerji takası sistemini yeniden kurmuştur. Anlaşmalar uyarınca havza su birliklerine su salımı, enerji transferinin zamanlaması ve transfer edilecek enerjinin miktarı dâhil birçok konuda geniş yetkiler verilmiştir. ${ }^{8}$

Havza sularının yönetiminde iş birliğini esas alan bu anlaşmalar, bağımsıllı̆̆ takip eden kısa bir süre boyunca (1992-1998 yılları arasında) işlemiş ve Merkezî Asya’da enerji ve su alanlarında bütünleşme ve iş birliğine yönelik umutları artırmış̧ır (Spoor vd. 2003: 593-614, Wegerich vd. 2007: 38153825, Pak vd. 2014). Ancak 1997-1998 döneminden itibaren (Kayumov 2012: 86) bölge ülkeleri otonom politikalar izlemeye başlamış, memba ülkelerin hidroelektrik enerji üretme hedefleri mansap ülkelerde endişe yaratmaya başlamıştır (Wegerich 2008: 85-86). Özbekistan, bu endişelerden dolayı yıllar boyunca Kırgızistan ve Tacikistan'daki Kambarata ve Rogun gibi baraj projelerini engellemiş, bölge su siyasetine ağırlığını koymuştur (Sojamo 2008).

Son yıllarda, Özbekistan'daki hükûmet değişiminin etkileriyle Merkezî Asya'da su yönetimi alanında iş birliğine yönelik adımlar atılmıştır. Örneğin Özbekistan Devlet Başkanı Şevket Mirziyayev'in Tacikistan'daki büyük baraj projelerine yönelik tutumunda yumuşamalar gözlemlenmiştir (Michel 2017, Sorbello 2018). Diğer yandan Kırgızistan ve Tacikistan hükûmetleri, iktisadî büyüme açısından vazgeçilmez olarak gördükleri büyük baraj ve hidroelektrik santral projelerini gerçekleştirmeye bir adım daha yaklaşmışlardır (Salini Impreglio 2017, Phys.org 2018). Ayrıca bir süreden beri Özbekistan başta olmak üzere Merkezî Asya ülkelerinde fert başı sulanan tarım arazisinin azalma eğiliminde olması (Avrasya Kalkınma 
Bankası 2008: 7-8, Rakhmatullaev vd. 2017: 13) ve Özbekistan'ın pamuk ekonomisi olmaktan giderek uzaklaşması (Abdullaev vd. 2009, Sakal 2017), Aral havzasındaki su sorununun çözülmesine yönelik olumlu gelişmelerdir.

\section{Kura-Aras havzası}

Kura-Aras havzasındaki önemli sorun alanları, su baskınları, akış miktarındaki düzensizlik ve kirlilik olarak sıralanabilir. Bölgedeki elektrik ticareti ve naklinin altyapısı ise gerek hukuki gerekse fiziksel açıdan görece az gelişmiş durumdadır. Birinci sorun alanı daha çok Azerbaycan'ı ilgilendirmektedir. Azerbaycan bir yandan kuraklık problemi yaşarken (Ubilava 2004: 2, Standardised Precipitation-Evapotranspiration Index 2016) diğer yandan deniz seviyesinin altında bulunan konumunun etkisiyle sellerden zarar görmektedir (Musayeva 2013: 71, Hasanova vd. 2010: 127, Babakhanov vd. 2012: 431, Musayeva 2013: 70). Sellerin yarattığ tahribattan korunmak için 1953 yılında Mingeçevir rezervuarı inşa edilmiştir (Aliyev vd. 2011: 429). Fakat nehirlerin taşıdığı alüvyonların rezervuarlarda birikmesi, rezervuarların su tutma kapasitesini düşürdüğü için (Mammedov 2006: 233-234, Mammadov vd. 2009), rezervuar inşası su baskınları açısından geçici bir çözüm olarak görülmektedir (Babakhanov vd. 2012: 431).

İkinci sorun alanı, Kura-Aras havzasında yirminci yüzyılın ortalarından itibaren akış miktarında gözlemlenen düzensizliktir (Leummens vd. 2013: 24-25). Bununla ilgili olarak son yıllarda Türkiye tarafından başlatılan hidroelektrik santral inşaatları ile sulama projeleri, mansap ülkelerde (özellikle Ermenistan’da) endişeye yol açmaktadır (Klaphake vd. 2011: 269, Yu vd. 2014: 26). Türkiye ile Ermenistan arasında bağımsızlık sonrası yaşanan siyasî sıkıntılara rağmen, yukarıda bahsedilen anlaşmaların da etkisiyle (ECC Platform) sınıraşan sular konusunda kayda değer anlaşmazlık yaşanmamıştır (Schwind 2018). Türkiye'nin 2010'un başından itibaren havzaya inşa ettiği ve etmeyi planladığı barajlar ve hidroelektrik santraller (Enerji ve Tabii Kaynaklar Bakanlığı 2017), ${ }^{9}$ Kura-Aras havzası ülkelerinin gündeminde pek yer bulmasa da ilerleyen yıllarda bu yapılar veya benzer projeler havza ülkeleri arasında sorun alanları olarak ortaya çıkabilir. Bu nedenle memba ülke konumundaki Türkiye'nin bölge ülkeleri arasındaki iş birliği ve elektrik ticareti çabalarına dâhil edilmesi kadar Türkiye'nin su politikaları ve hidroelektrik ticareti yaklaşımı da havza su politikaları açısından önemlidir. 


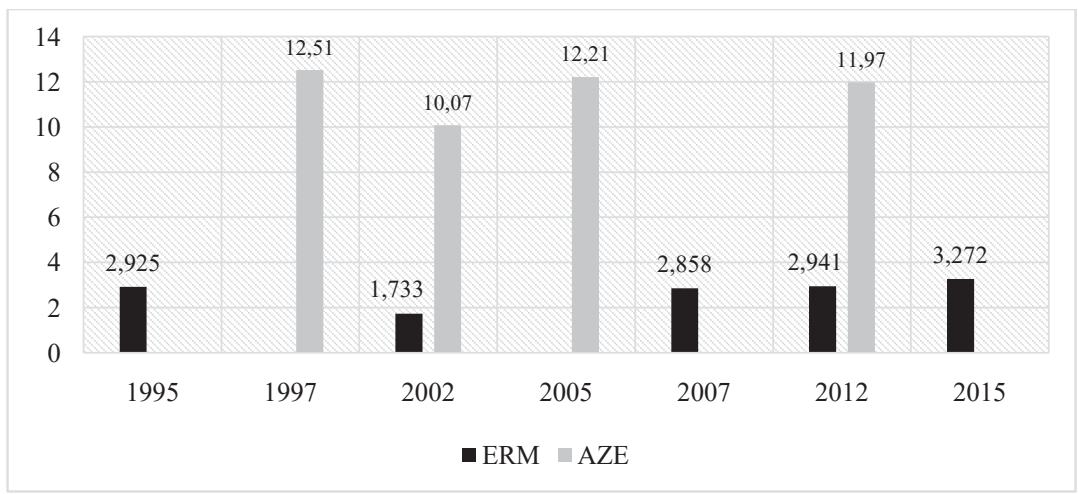

Şekil 3. Ermenistan ve Azerbaycan'in toplam su tüketimi (milyar metreküp)

(World Bank 2018).

Kura-Aras havzasının üçüncü önemli sorunu olan kirlilik, SSCB döneminde yakından takip edilen bir konuydu. Sovyetlerin dağılmasından sonra kapanan sanayi tesisleri ve madenler 2000'lere kadar sanayi kaynaklı kirliliğin azalmasına (Betsiashvili vd. 2007: 38) ve Ermenistan ile Azerbaycan'in sanayi sektörlerinin su tüketiminin düşmesine (Ubilava 2004: 2) katkıda bulunmuştur. Ne var ki, bağımsızlıktan sonra havza ülkeleri tarafından ikinci plana atılmaya başlanan kirlilik konusu (Abbasov vd. 2009: 1070) 2000'lerin ortasından itibaren artan sanayi üretimiyle birlikte tekrar gündeme gelmiştir. Bölgede su tüketimi (Şekil 3) ve ağır metallerden kaynaklı kirlilik artmaya devam etmektedir (Ewing 2003: 10). Ermenistan' in ve Azerbaycan'ın resmî kuruluşları havzada temiz suya erişimin sorunlu bir hal aldığını bildirmektedirler (EIMCA 2016: 20-24, MENRA 2017). Azerbaycan'da bağımsızlıktan hemen sonra yüzde 69 seviyesinde olan temiz su kaynaklarına erişim oranı (World Health Organization 2015), son yıllarda kaydedilen düzelme ile yaklaşık yüzde 87 seviyesine gelebilmiştir. Yine de bu oran yeterli değildir.

Kura-Aras havzasında, Aral havzasındakine benzeyen ve elektrik takasını sağlayan teknik bir altyapı ile çeşitli hukuki düzenlemeler mevcuttur. Ancak bu teknik altyapı, havza ülkelerinin tamamını dâhil edecek şekilde tasarlanmamıştır. Sovyet döneminde kurulan bu sistemde Ermenistan'daki nükleer, Azerbaycan'daki termik ve Gürcistan'daki hidroelektrik santraller eşgüdümlü çalışarak üç Sovyet cumhuriyetine hizmet vermiştir (Opitz 2015: 26-27). Bölgesel iktisadî bütünleşmenin örneklerinden olan bu 
yapı, 1990’lı yıllarda işlerliğini yitirmiştir. Günümüzde ise bu sistemi temel alan, Türkiye ve İran'ı da kapsayan bir hidroelektrik enerji entegrasyonu oluşturulması mümkündür.

Bölge ülkeleri arasında iş birliğini sağlayabilecek hukuki düzenlemelerse sınırlıdır. Sovyet hükûmeti, 1927 yılında Türkiye ile suların eşit paylaşımını öngören bir sınır anlaşması imzalamıştır (Kanunlar Dergisi 1927) ${ }^{10}$ ve anlaşmanın ek protokolü ile nehirler üzerinde kurulacak su yapılarının inşası düzenlenmiştir (Kanunlar Dergisi 1927). İki ülke arasında Ekim 1973'te imzalanan diğer anlaşma, sınır oluşturan Arpaçay Nehri üzerinde baraj inşasını konu edinmiştir (Resmî Gazete 1975, Punsmann vd. 2012: 13-14). ${ }^{11}$ Türkiye ile İran arasında, Kura-Aras havzasındaki Sarısu ve Karasu nehirlerinin sularının paylaşımını düzenleyen bir anlaşma, Kasım 1955'te imzalanmıştır (Klaphake vd. 2011: 266, Orhon 2015: 122). SSCB ve İran ise 1957 yılında su ve enerji paylaşımını düzenleyen bir anlaşma yapmışlardır (Hirsch 1959, UNDP/GEF 2007). Bu anlaşmalarla Kura-Aras havzasında su yönetimi konusu kısmen düzenlenmiş olsa da hem anlaşmaların üzerinden geçen sürede yaşanan önemli uluslararası siyasî gelişmeler hem de anlaşmalarla çözüme kavuşturulmamış seller (Mammadov vd. 2009), su kalitesi ölçümü ve takibi (Muradyan vd. 2013), su kirliliği (Abbasov vd. 2009: 1070) gibi önemli sorunların varlığı (Leummens vd. 2013: 7) yeni ve kapsayıcı bir havza yönetimi yaklaşımının ve havza temelli iş birliğinin gerekliliğini ortaya koymaktadır.

\section{Havzaların sorun alanlarının karşılaştırılması}

Havzaların ortak meselelerinin başında sulu tarım gelmektedir. İki havzada da su kullanımının büyük çoğunluğu tarım sektörüne aittir. Sulu tarımın en fazla uygulandığ ve güney kesimleri, Gürcistan’ın güneyi ve Türkiye'de Iğdır Ovası'dır. Aral havzasındaysa sulu tarım bölgeleri mansap ülkelerde Seyhun ve Ceyhun boyları ile Fergana Vadisi'dir. Sulu tarım uygulamaları fiziksel su kıtlığının bulunduğu Aral havzasında önemli bir baskı unsuru oluşturmaktayken Kura-Aras havzasında (Leummens vd. 2013: 7) henüz bu boyutta bir sorun söz konusu değildir (Kayumov 2012). ${ }^{12}$ İki havzada da yoğun sulu tarım uygulanan mansap ülkeler Özbekistan ve Azerbaycan'da yüksek su bağımlılık oranları kaydedilmektedir. Aradaki önemli bir fark, Özbekistan'daki tarımsal su tüketiminin Azerbaycan'dakinin beş katından fazlası olmasıdır (Tablo 1). 
İki havzanın bir diğer ortak sorun alanı, havza ülkeleri arasında su yönetimi alanında iş birliğinin hukuki altyapısıyla ilgilidir. Aral havzasında, SSCB'nin dağılmasından sonra havza ülkeleri tarafından imzalanan bölgesel anlaşmalarla çevre, enerji ve tarım alanları kapsamlı şekilde düzenlenmiştir. Kura-Aras havzasındaysa tüm sorun alanlarını ele alan ve havza ülkelerinin tamamı tarafından imzalanmış bulunan bölgesel anlaşma yoktur. Bu durum, Kura-Aras havzasında su yönetiminde önemli bir eksiklik olarak değerlendirilmektedir. Bir başka eksiklikse havzada elektrik ticaretini veya entegrasyonunu düzenleyen anlaşmanın bulunmayışıdır. Diğer taraftan Kura-Aras havzasındaki ülkeler arasında imzalanan ikili anlaşmalarla (Türkiye-Ermenistan gibi) önemli iş birlikleri sağlanmıştır ve ülkeler arası siyasî meselelere rağmen bu anlaşmalar halen yürürlüktedir.

Diğer bir sorun alanı, ülkelerin su kaynaklarına yönelik farklı önceliklerinin bulunmasıdır. Aral havzasında Özbekistan'ın tarım sektörü, Kırgızistan’ın ve Tacikistan'ın hidroelektrik endüstrilerinin genişleme programlarıla çatışma halindeyken; Kura-Aras havzasında Türkiye hidroelektrik üretimini artırmayı, Gürcistan ve Ermenistan su kirliliğini azaltmayı, Azerbaycan ise sellerden korunmayı ve tarım sektörünü geliştirmeyi öncelikleri arasına almıştır. Bu durum, bölgesel entegrasyonun önündeki önemli engellerdendir ve havzalarda tüm ülkelerin kabul edebileceği çözüm süreçlerinin ortaya çıkmasını güçleştirmektedir. Diğer taraftan, her iki havzadaki su, enerji ve çevre sorunları ve bunlara yönelik çözüm önerileri küresel ve bölgesel kuruluşların gündemindedir. Türk Keneşi veya Türk Dili Konuşan Ülkeler Parlamenter Asamblesi gibi kuruluşların çalışmaları hem Merkezî Asya hem de Kafkasya bölgelerini aynı anda kapsamaları bakımından önem arz etmektedir (Idrissov 2015, TürkPA 2016).

Bu makale, her iki havzayı kapsayan bu sorun alanlarının, bir sonraki bölümde tartışılacağı üzere, ticaret temelli iş birliği modelleriyle çözülebileceğini öne sürmektedir.

\section{Bir Çözüm Önerisi Olarak Hidroelektrik Ticareti}

Aral ve Kura-Aras havzalarındaki enerji takas sistemleri, Sovyet cumhuriyetlerinin elektrik şebekelerini birbirine bağlayarak entegrasyonu ve enerji kaynaklarının etkin yönetimini sağlamaktaydı. Aral havzasında hidroelektrik ticareti ile su yönetimi ve çevre konuları arasındaki yakın ilişki, 
güncel çalışmalarda kapsamlı şekilde ele alınmıştır (Tanrısever vd. 2017). Kura-Aras havzası özelinde ise, planlı ekonomi döneminde kurulmuş olan takas sistemlerinin bir benzeri günümüzde Türkiye ve İran'ı da içine alan havza temelli elektrik enerjisi bütünleşmesinin alt yapısını oluşturabilir.

Türkiye ile hidroelektrik alanında iş birliği, ilk etapta Gürcistan, uzun vadedeyse Azerbaycan ve Ermenistan için büyük fırsatlar barındırmaktadır. Örneğin, 2016'dan itibaren Türkiye'nin AB enerji havuzuna (ENTSO$E)^{13}$ dâhil olması (TEİAŞ 2017), Güney Kafkasya ülkelerinin AB elektrik pazarıyla komşu olmalarını sağlamıştır. Bu sayede oluşacak elektrik ticareti, Gürcistan başta olmak üzere Güney Kafkasya ülkelerine, yenilenebilir enerji kaynaklarından ürettikleri enerjiyi yeni pazarlara ulaştırma fırsatı sunabilir.

Burada önerilen model çerçevesinde, Kura-Aras havzasında Türkiye ve Gürcistan'ın, Aral havzasındaysa Tacikistan ve Kırgızistan'ın havzayı besleyen nehirlerden hidroelektrik enerji üretimini artırmalarıla mansap ülkelere yönelen su akış miktarının azalmaması için havza ülkelerinin, hidroelektrik ve çevresel akış ihtiyaçları dâhil birçok konuda iş birliği içinde hareket etmeleri gerekmektedir. Bu çerçevede, Kura-Aras havzasında görece az gelişmiş olan elektrik ticareti, ikili veya bölgesel teknik anlaşmalar ile güçlendirilebilir. Merkezî Asya'da ise hukuki ve teknik altyapısı mevcut fakat işlevini yitirmiş olan (Gullette vd. 2014: 439) takas sistemi (MAGS) kısa sürede teknoloji yatırımlarıyla tekrar işler hale getirilebilir. Burada havza ülkeleri arasında sınıraşan enerji nakil hatlarının inşasına ve var olanların geliştirilmesine öncelik verilmelidir.

Dolayısıyla, Balassa (1961) tarafindan önerilen güdümcü yaklaşıma dayalı ticaret temelli bütünleşme modeli çerçevesinde, Aral ve KuraAras havzalarında ikili elektrik ticaretine bağlı iş birliği geliştirilebilir. Bu iş birliklerinin gelişimiyse, elektrik şebekelerinin entegrasyonuyla elde edilecek iktisadî ve teknik kazanımların (Pineau vd. 2004, Pierce vd. 2006) bölge ülkeleri tarafından dikkate alınması sayesinde mümkün olacaktır. Söz konusu bölgelerde sınıraşan nehir havzalarındaki su yönetimi problemleri ikili elektrik ticaretinin geliştirilmesiyle hafifletilebilir. Havza ülkelerinin hükûmetlerinin siyasî iradeleri bu noktada belirleyici olacaktır. 


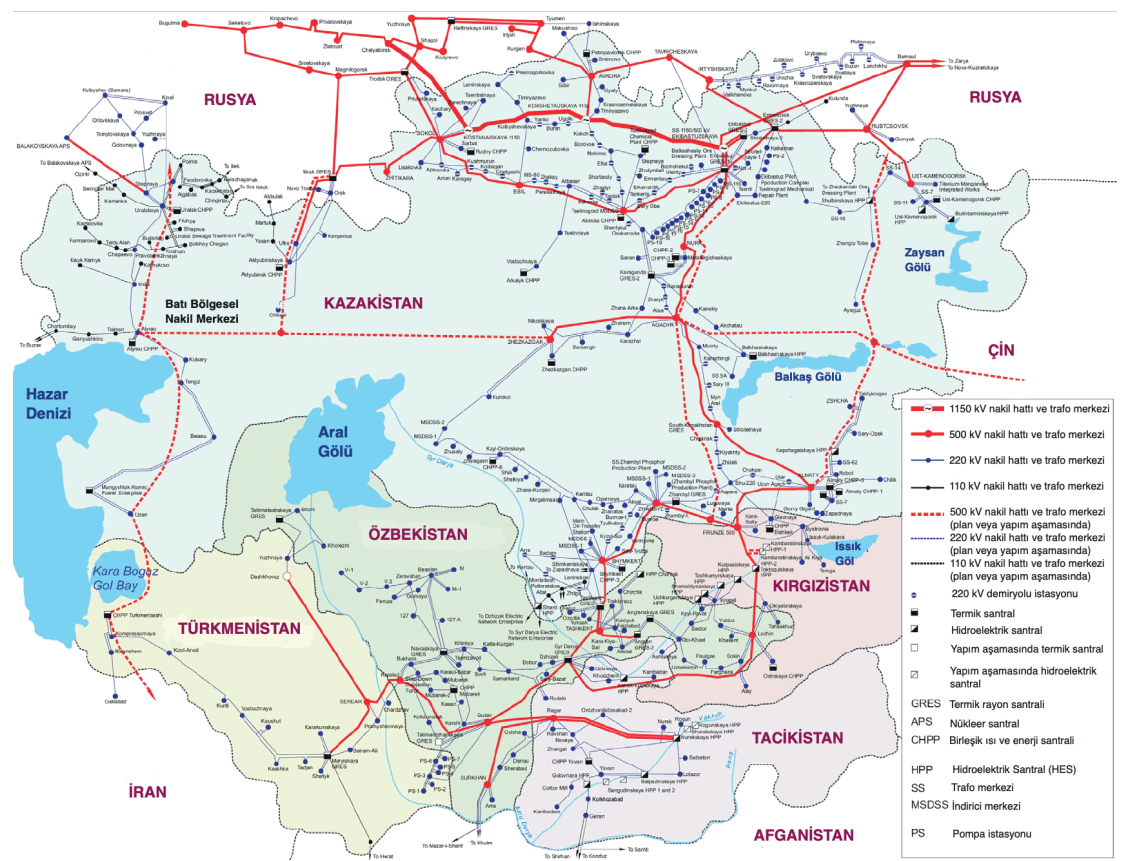

Şekil 4. Merkezî Asya Gü̧̈ Sistemi (MAGS) (Global Energy Network Institute 2015).

\section{Sonuç}

Aral ve Kura-Aras havzalarına yönelik çevresel sorunlar birbirlerine benzer şekilde SSCB'nin dağılmasının ardından artmıştır. Bu iki havzayı ilgilendiren teknik ve uluslararası hukuki düzenlemelerin güncellenmeleri ve işler hale getirilmeleri önemlidir. Aral havzası özelinde bu yönde bölgesel çabalar olsa da çözüme yönelik kayda değer bir ilerleme olmamıştır. KuraAras havzasının ise bu açıdan kapsamlı şekilde ele alınması gerekmektedir.

Havzalar bahsi geçen konular bağlamında benzerlik gösterse de her iki havzanın kendine özgü çözüm bekleyen sorun alanları mevcuttur. Bu sorun alanlarının havza temelli ve iş birliği esaslı bir şekilde ele alınması önemlidir. Eski Sovyet coğrafyası üzerine geliştirilen kuramsal bütünleşme yaklaşımları siyasî iş birliğinin kısa vadede düşük ihtimal olduğuna vurgu yapmaktadır. $\mathrm{Bu}$ nedenle havza ülkeleri arasında ikili hidroelektrik ticareti konuları gündeme gelmeli, bu kapsamda çözüme yönelik adımlar atılmalıdır.

Gerek Kura-Aras, gerekse Aral havzalarında bölgesel elektrik enerjisi ticareti veya takasının altyapısının halihazırda bulunuyor olması, bu çözüm 
önerisinin yenileme yatırımlarıyla kısa süre içinde hayata geçirilebilmesi ihtimalini barındırması açısından umut vericidir. Her ne kadar Güney Kafkasya ve Merkezî Asya'daki altyapılar günümüzde işlemiyor olsa da tarihsel örnekler, bu tür enerji alışverişlerinin geçmişte yapılabildiğinin ve dolayısıyla bugün de yapılabileceğinin göstergesidir. Her iki bölgede ülkeler arasında imzalanan ve enerji ticaretini düzenleyen anlaşmaların varlığ bu anlamda önemlidir. Ancak elektrik enerjisi ticaretini bölgesel iş birliği bağlamından bütünleşme seviyesine yükseltebilmek için daha kapsamlı adımların gerektiği ortadadır.

Merkezî Asya'da memba ülkelerin hidroelektrik santrallerinin mansap ülkelerin enerji ağlarına bağlanması ve koordineli çalışması, bölgesel su yönetimi ve enerji sorunlarına ciddi katkı yapabilecek bir politika olacaktır. Güney Kafkasya bölgesi açısından ise bu öneri göründügüünden daha yakın bir ihtimal olabilir. AB'nin ENTSO-E sistemine bağlı olan Türkiye üzerinden Gürcistan'ın hidroelektrik santralleri Avrupa pazarına bağlanabilir. Bunun bir sonraki aşamasıysa tüm Kura-Aras havzasının AB elektrik şebekesine bağlanması olacaktır ki bu seçenek hem AB'nin yenilenebilir enerji arz güvenliği hem de bölgesel su yönetimi sorunları açısından olumlu bir gelişme olarak değerlendirilebilir. Son olarak, su yönetimi sorunlarına elektrik ticaretiyle çözüm modeli, konunun teknik bir bağlamda kalması nedeniyle bölgesel siyasetçiler ve liderler açısından daha kabul edilebilir bir seçenek olarak ortaya çıkmaktadır.

\section{Açıklamalar}

1. Türkistan coğrafyası bu makalede, Kazakistan’ı bölgeden ayrı tutan Rusça literatürdeki Srednyaya Aziya (Orta Asya) terimi yerine İngilizce literatürdeki Central Asia terimi veya Rusçadaki Tsentralnaya Aziya teriminin Türkçe'deki karşılığı olan Merkezî Asya olarak adlandırılacaktır.

2. Literatürde hidroelektrik ticaretinin faydalarına odaklanan çalışmaların yanında bu konuya eleştirel yaklaşan çalışmalar da mevcuttur. bk. De Villemeur vd. 2012.

3. İktisadi bütünleşme teorilerini analiz eden kapsamlı bir literatür taraması için, bk Hosny 2013.

4. Aral Gölü’nün kurumasıyla eskiden suyun bulunduğu göl yatağındaki tuzlu kum, her yıl kum fırtınaları ile uzak coğrafyalara taşınmaktadır. Bu fırtınalar, buzullarla kaplı dağlara kadar ulaşabilmekte ve buradaki buzulların 
erimesini hızlandırmaktadır. Bu durum, küresel çapta bir çevre sorununa işaret etmektedir (Columbia University 2008). Bu sorun birçok yazar tarafindan etraflıca tartışılmıştır. bk. Brown 1991; Aladin, vd. 1995; Bedford 1996; Zholdasova 1997; Whish-Wilson 2002; Small, vd. 2003; Badescu vd. 2010; Harriman 2014; Micklin 2016.

5. Merkezî Asya Güç Sistemi, 1970’li yıllarda Merkezî Asya’da inşa edilen ve Özbekistan, Kırgızistan, Tacikistan, Türkmenistan ile Kazakistan'ın güneyini kapsayan bir elektrik iletim hattı şebekesidir. Bu şebeke Özbekistan'daki merkezden idare edilmekteydi ve birbiriyle eşgüdüm içinde çalışan termal ve hidroelektrik enerji santrallerin ultra yüksek voltaj enerji nakil hatları ile birbirine bağlanmasından müteşekkildi (World Bank 2015). Konu ile ilgili diğer önemli kaynaklar için bk. World Energy Council 2007; World Bank 2010; Murphy 2014; Global Energy Network Institute 2015.

6. Ortak Su Kaynakları Yönetimi ve Devletlerarası Kaynakların Korunması Alanlarında İş Birliği Anlaşması. İngilizce metni için bk. Agreement between the Republic of Kazakhstan, the Republic of Kyrgyzstan, the Republic of Uzbekistan, the Republic of Tajikistan and Turkmenistan on cooperation in the field of joint water resources management and conservation of interstate sources 1992, http://www.icwc-aral.uz/statute1.htm. (Erişim tarihi: 30 Kasım 2018).

7. Havza su birlikleri sulama ve drenaj ağlarını yönetmek üzere çiftçilerden oluşan otonom yönetime sahip gruplardır. Ayrıntılı bilgi için bk. Abdullaev vd. 2015; Abdullaev 2012; Zavgorodnyaya 2006.

8. Anlaşmaların İngilizce metinleri için bk. "Agreement Between the Government of the Republic of Kazakhstan, the Government of the Kyrgyz Republic and the Government of the Republic of Uzbekistan on Joint and Complex Use Water and Energy Resources of the Naryn Syr Darya Cascade Reservoirs in 1998.” (1998, Mart 17). Bişkek. http://www.ce.utexas.edu/prof/mckinney/ papers/aral/agreements/Annual-Operation-98.pdf. [Erişim: 30 Kasım 2018]. "Agreement between the Governments of the Republics of Kazakhstan, the Kyrgyz Republic, the Republic of Tajikistan, and the Republic of Uzbekistan on the Parallel Operation of the Energy Systems of Central Asia." (1999). Bişkek. http://www.cawater-info.net/library/eng/l/parallel-agreement.pdf. (Erişim tarihi: 30 Kasım 2018).

9. Türkiye Kura Nehri ve kolları üzerine bir dizi baraj inşa etmiştir. Bunlardan bazıları 2014 yılında inşa edilen Kayabeyi Barajı (Devlet Su İşleri 2014) ve 2016 yılında inşa edilen Köroğlu Barajı'dır. Kura üzerinde Burmadere, Durançam (Devlet Su İşleri 2016) gibi barajların yapımı ise devam etmektedir. 


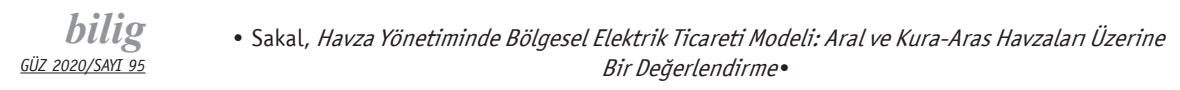

10. Türkiye Cümhuriyeti ile Sosyalist Şûralar Cümhuriyeti İttihadı Hudutlarını Teşkil Eyleyen Nehir, Çay ve Dere Sularından İstifadeye Dair Mukavelename.

11. Türkiye Cumhuriyeti Hükûmeti ile Sovyet Sosyalist Cumhuriyetleri Birliği Hükûmeti Arasında Sınırdaki Arpaçay (Ahüryan) Nehrinde Baraj İnşası ve Baraj Gölünün Teşekkülü Konusunda İşbirliğine Dair Anlaşma.

12. Su kıtlığı, suya erişim, su kalitesi, çevresel akış ve benzeri teknik içerikli bilgi için, bk. Nepomilueva 2017. Ayrıca benzer başka göstergeler ve hesaplama yöntemleri için, bk. Brown vd. 2011.

13. European Network of Transmission System Operators for Electricity (Avrupa Elektrik İletim Sistemi İşleticileri Ağı).

\section{Kaynaklar}

Abbasov, Rovshan K. \& Vladimir U. Smakhtin (2009). "Introducing environmental thresholds into water withdrawal management of mountain streams in the Kura River basin, Azerbaijan”. Hydrological Sciences Journal 54 (6): 10681078.

Abdolvand, Behrooz vd. (2015). "The dimension of water in Central Asia: security concerns and the long road of capacity building”. Environmental Earth Sciences 73 (2): 897-912.

Abdullaev, Iskandar vd. (2009). "Agricultural Water Use and Trade in Uzbekistan: Situation and Potential Impacts of Market Liberalization". Water Resources Development 25 (1): 47-63.

Abdullaev, Iskandar (2012). The Socio-Technical Aspects of Water Resources Management in Central Asia. Saarbrücken: LAP Lambert.

Abdullaev, Iskandar \& Shavkat Rakhmatullaev (2015). “Transformation of Water Management in Central Asia: From State-Centric, Hydraulic Mission to Socio-Political Control”. Environmental Earth Sciences 73 (2): 849-861.

Agayeva, Aygül (2017). "Orta Asya'da Su Sorunu: Havzalar ve Barajlar”. Uluslararası Afro-Avrasya Araştırmalar Dergisi 1 (3): 35-62.

Ahmadli, Orkhan (2017). Regional integration dynamics in South Caucasus. The Politicon: http://thepoliticon.net/analytics/348-regional-integrationdynamics-in-south-caucasus.html\#sel=1:1,1:6 (Erişim Tarihi: 24.10.2018).

Aladin, Nikolai Vasil'evich vd. (1995). "The Aral Sea desiccation and possible ways of rehabilitating and conserving its northern part”. Environmetrics 6 (1): 17-29.

Aliyev, V. vd. (2011). "Mingechevir Embankment Dam Collapse: Catastrophic Risk Analysis and Management". Proceedings of the International Congress "Natural Cataclysms and Global Problems of the Modern Civilization". İstanbul: SWP. 429-430. 
Arsel, Murat \& Max Spoor (2010). "Follow the Water"., Water, environmental security and sustainable rural development: conflict and cooperation in Central Eurasia. Eds. M. Arsel and M. Spoor. London: Routledge. 3-17.

Avrasya Kalkınma Bankası (2008). Water and Energy Resources in Central Asia: Utilization and Development Issues. Almaty: Eurasian Development Bank. http://eabr.org/general/upload/docs/Report_2_water_and_energy_EDB. pdf (Erişim Tarini: 12 Temmuz 2018).

Aynagöz Çakmak, Özge (2017). "Orta Asya: Bölgesel Entegrasyon Girişimleri ve Öneriler”. Sosyal Ekonomik Araştırmalar Dergisi (The Journal of Social Economic Research) 17 (33): 116-133.

Babakhanov, N. \& M. Musayeva (2012). "Flood Fighting Methods in the Kura and Araz rivers". Proceedings of the International Congress "Natural Cataclysms and Global Problems of the Modern Civilization”. İstanbul: SWB. 430-433.

Badescu, Viorel \& Roelof D. Schuiling (2010). "Aral Sea; Irretrievable Loss or Irtysh Imports?”. Water Resources Management 24 (3): 597-616.

Balassa, Bela (1961). The Theory of Economic Integration. Homewood: Richard D. Irwin.

Balassa, Bela (1965). Economic Development and Integration. Mexico: Centro De Estudios Monetario Latinoamericanos.

Balassa, Bela (1994). "The Theory of Economic Integration: An Introduction". The European Union. Ed. B.F. Nelsen and A.CG. Stubb. Londra: Palgrave.

Balassa, Bela \&Ardy Stoutjesdijk (1975). "Economic Integration among Developing Countries". JCMS: Journal of Common Market Studies 14 (1): 37-55.

Barabadze, Tamar (2003). "Water Management in the South Caucasus". EuroMediterranean Information System on the know-how in Water sector. http:// www.bvsde.paho.org/bvsacd/wwf3/cauca.pdf (Erişim Tarihi: 20.10.2017).

Baritaud, Manuel \& Dennis Volk (2014). Seamless Power Markets: Regional Integration of Electricity Markets in IEA Member Countries. Paris: OECD/ IEA. https://www.iea.org/publications/freepublications/publication/ SEAMLESSPOWERMARKETS.pdf (Erişim Tarihi: 28.9.2018).

Bedford, Dan P. (1996). "International Water Management in the Aral Sea Basin”. Water International 21 (2): 63-69.

Betsiashvili, Mariam \& Mariam Ubilava (2007). "Water Quality and Wastewater Treatment Systems in Georgia”. Dangerous Pollutants (Xenobiotics) in Urban Water Cycle. Ed. P. Hlavinek vd. Lednice: Springer. 35-45.

Bhambri, Ranjit. S. (1962). "Customs unions and underdeveloped countries". Economia Internazionale (Mayı).

Bichsel, Christine vd. (2010). "Natural Resource Institutions in Transformation: The Tragedy and Glory of the Private". Global Change and Sustainable Development: A Synthesis of Regional Experiences from Research Partnerships. 
Eds. H. Hurni and U. Wiesmann. Bern, University of Bern: Geographica Bernensia. 255-269.

Birleşmiş Milletler (2018). Cooperation between the United Nations and the International Fund for Saving the Aral Sea. Washington, DC: UN General Assembly. http://digitallibrary.un.org/record/1477554/files/A_72_L-42-EN. pdf (Erişim Tarihi: 29.09.2018).

Bland, Stephen M. (2015). Kazakhstan: Measuring the Northern Aral's Comeback. Eurasianet: http://www.eurasianet.org/node/71781 (Erişim Tarihi: 20.07.2018).

Bohr, Annette (2004). "Regionalism in Central Asia: New Geopolitics, Old Regional Order". International Affairs (Royal Institute of International Affairs 1944-) 80 (3): 485-502.

Brown, Amber \& Marty D. Matlock (2011). A Review of Water Scarcity Indices and Methodologies. Arkansas: Sustainability Consortium.

Brown, Lester R. (1991). “The Aral Sea: Disaster Area and Interdisciplinary Solution”. Interdisciplinary Science Reviews 16 (4): 345-350.

CA Water (2018). Aral Sea. http://www.cawater-info.net/arallindex_e.htm. (Erişim Tarihi: 2.11.2018).

Campana, Michael E., Berrin Basak Vener \& Baek Soo Lee (2012). "Hydrostrategy, Hydropolitics, and Security in the Kura-Araks Basin of the South Caucasus". Journal of Contemporary Water Research \& Education (149): 22-32.

Campana, Michael E. vd. (2008). "Science for Peace: Monitoring Water Quality and Quantity in the Kura-Araks Basin of the South Caucasus". Transboundary Water Resources: A Foundation for Regional Stability in Central Asia. Eds. J. E. Moerlins vd. Dodrecht: Springer. 153-170.

CAREC (2018). The Central Asian International Environmental Forum 2018 Started. CAREC: https://carececo.org/en/main/news/news/CAIEF2018-1/ (Erişim Tarihi: 29.09.2018).

Chiragov, Fuad \& Reshad Karimov (2015). "Policies from afar: the US options towards greater regional unity in the South Caucasus". The South Caucasus Between integration and fragmentation. SAM ve European Policy Centre. 95-101. http://www.epc.eu/documents/uploads/pub_5598_article_-_fuad_chiragov_ and_reshad_karimov.pdf?doc_id=1636 (Erişim Tarihi: 28.09.2018).

Columbia University (2008). Environmental Impacts. The Aral Sea Crisis: http:// www.columbia.edu/ -tmt2120/environmental\%20impacts.htm (Erişim Tarihi: 19.09.2018).

Craumer, Peter R. (1992). "Agricultural Change, Labor Supply, and Rural OutMigration in Soviet Central Asia”. Geographic Perspectives on Soviet Central Asia. Ed. R. A. Lewis vd. New York: Routledge. 129-175.

De Villemeur, Etienne Billette \& Pierre-Olivier Pineau (2012). "Regulation and 
electricity market integration: When trade introduces inefficiencies". Energy Economics 34 (2): 529-535.

Devlet Su İșleri (2014). Ardahan İli Kura Nehri Kayabeyi Barajinda Su Tutuldu. DSİ Haberler: https://goo.gl/rDMGgR (Erişim Tarihi: 23.07.2018).

Devlet Su İşleri (2016). Durançam Barajı İnşaatı Sözleşmesi İmzalandı. DSİ Haberler: https://goo.gl/mQxFCZ (Erişim Tarihi: 23 Şubat 2018).

ECC Platform (ty.). Turkey-Armenia: Water Cooperation Despite Tensions. ECC Factbook: https://library.ecc-platform.org/conflicts/turkey-armenia-watercooperation-despite-tensions\#panel3a (Erişim Tarihi: 20.7.2018).

EIMCA (2016). The Ecological Monitoring Results. Ministry of Nature Protection. Yerevan: Ministry of Nature Protection.

Elma, Fikret (2014). "Küreselleşme Sürecinde Güney Kafkasya Demokrasi, Güvenlik ve İşbirliği Sorunu." II. Uluslararası Sosyal Bilimciler Kongresi. Bişkek. (22-24 Ekim).

Enerji ve Tabii Kaynaklar Bakanlığı (2017). İllerin Enerji Görünümü. Yenilenebilir Enerji Genel Müdürlüğ̈̈: http://www.yegm.gov.tr/il_enerji.aspx (Erişim Tarihi: 30.11.2018).

ESA (2018). European Space Agency. Aral Sea, Kazakhstan - Recovery of the Island Sea: https://earth.esa.int/web/guest/missions/esa-operational-eo-missions/ proba-v/image-of-the-week/-/article/aral-sea-kazakhstan-2018 (Erişim Tarihi: 18.07.2018).

EU Water Initiative for Eastern Partnership (2018). The Kura Aras River Basin. https:// euwipluseast.eulenlabout/pilot-river-bassin/kura (Erişim Taribi: 02.11.2018).

Ewing, Amy (2003). Water Quality and Public Health Monitoring of Surface Waters in the Kura-Araks River Basin of Armenia, Azerbaijan, and Georgia. Water Resources Program. New Mexico: University of New Mexico.

FAO (2009). Kura Araks Basin. Food and Agriculture Organization: http://www. fao.org/nr/water/aquastat/basins/kura-araks/indexesp.stm (Erişim Tarihi: 19.07.2018).

FAO (2016). AQUASTAT Main Database. Food and Agriculture Organization of the United Nations: http://www.fao.org/nr/water/aquastat/data/query/index. html?lang=en (Erişim Tarihi: 19.11.2018).

Gasimli, Vusal (2015). "Trade, economic and energy cooperation: challenges for a fragmented region". The South Caucasus Between integration and fragmentation. SAM ve European Policy Centre. 61-66. http://www.epc.eu/documents/ uploads/pub_5598_article_-_vusal_gasimli.pdf?doc_id=1640 (Erişim Tarihi: 16.10.2018).

Global Energy Network Institute (2015). Central Asian Grid. http://www.geni. org/globalenergy/library/national_energy_grid/central-asia/central-asianelectricitygrid.shtml (Erişim Tarihi: 30.11.2018). 
Granit, Jakob vd. (2014). "Regional Options for Addressing the Water, Energy and Food Nexus in Central Asia and the Aral Sea Basin". Water and Security in Central Asia: Solving a Rubik's Cube. Eds. V. Stucki vd. New York: Routledge. 25-38.

Gullette, David \& Jeanne Féaux de la Croix (2014). "Mr Light and people’s everyday energy struggles in Central Asia and the Caucasus: an introduction". Central Asian Survey 33 (4): 435-448.

Haas, Ernst. B. (1961). "International Integration: The European and the Universal Process”. International Organization 15 (3): 366-392.

Harriman, Lindsey (2014). The future of the Aral Sea lies in transboundary co-operation. United Nations Environment Programme. https://goo.gl/acWVyK (Erişim Tarihi: 20.11.2018).

Hasanova, Naila \& Farda Imanov (2010). "Flood management in Azerbaijan". Infrastruktura i Ekologia Terenów Wiejskich 11: 127-134.

Hirsch, Abraham M. (1959). "Russian - Iranian Treaty of August 11, 1957". Middle East Journal 13 (2): 193-195.

Idrissov, Erlan (2015). “The Turkic Council: Engine of Turkic Integration”. Fifth Summit of the Turkic Council: A rising actor in regional cooperation in Eurasia. Ankara: Center for Strategic Research. 11-15. http://sam.gov.tr/wp-content/ uploads/2015/10/SAM-Report_-Fifth-Summit-of-the-Turkic-Council.pdf (Erişim Tarihi: 29.09.2018).

Kakachia, Kornely (2015). "Europeanisation and Georgian foreign policy”. The South Caucasus Between integration and fragmentation. 11-18. https://goo.gl/k2zY4u (Erişim Tarihi: 28.09.2018).

Kakhkharov, Jakhongir (2007). Regional Cooperation in Central Asia: Viewpoint from Uzbekistan. Münih: MPRA.

Kanunlar Dergisi (1927). "8 Kânûn-i Evvel 1926 Târîhinde Kars’ta İmzâ Edilen Sular I'tilâfnâmesiyle Serdârâbâd Barajının İnşâsına Dâir Müzeyyel Protokolün Tasdîkine Müteallik Kânûn”. Kanun No. 1168. Türkiye Büyük Millet Meclisi Tutanak Dergisi 649-650(5): 2-3. Ankara: TBMM. https://www. tbmm.gov.tr/tutanaklar/KANUNLAR_KARARLAR/kanuntbmmc005/ kanuntbmmc005/kanuntbmmc00501168.pdf (Erişim Tarihi: 16.02.2018).

Karasar, Hasan Ali ve Sanat Kuşkumbayev (2009). Türkistan Bütünleşmesi. İstanbul: Ötüken Yay.

Kayumov, Abdurasul (2012). "Water scarcity and interstate cooperation dynamics in Naryn/Syr Darya river basin”. Energy Policy 13 (3): 80-93.

Kindleberger, Charles P. (1963). "European Economic Integration and the Development of a Single Financial Center for Long-Term Capital”. Weltwirtschaftliches Archiv 90: 189-210.

Klaphake, Axel \& Annika Kramer (2011). "Kura-Aras River Basin: Burgeoning 
Transboundary Water Issues”. Turkey's Water Policy. Eds. A. Kibaroglu vd. Berlin: Springer. 263-275.

Leummens, Harald J. L. \& Mary. M. Matthews (2013). Updated Transboundary Diagnostic Analysis for the Kura Ara(k)s river basin. Tbilisi-Baku-Yerevan: UNDP/GEF.

Libman, Alexender \& Evgeny Vinokurov (2011). "Is it really different? Patterns of regionalization in post-Soviet Central Asia”. Post-Communist Economies 23 (4): 469-492.

Lipsey, Richard G. (1960). "The theory of customs unions: A general survey". The Economic Journal 70 (279): 496-513.

Mammadov, Ramiz Mahmud oglu \& Rafig Verdiyev (2009). "Integrated water resources management as basis for flood prevention in the Kura river basin". Workshop on Transboundary Flood Risk Management.

Mammedov, Rajab (2006). "Transboundary Floods in Azerbaijan. Transboundary Floods: Reducing Risks Through Flood Management. Eds. J. Marsalek vd. Dodrecht: Springer. 231-236.

Mankoff, Jeffrey (2012). The Big Caucasus: between fragmentation and integration. Washington, DC: CSIS. https://csis-prod.s3.amazonaws.com/s3fs-public/ legacy_files/files/publication/120326_Mankoff_BigCaucasus_Web.pdf (Erişim Tarihi: 27.09.2018).

McPherson, Ben (2014). South Caucasus Energy Integration: Market Snapshots. Brüksel: Energy Charter Secretariat Knowledge Centre. https://energycharter. org/fileadmin/DocumentsMedia/Occasional/Caucasus_Energy.pdf (Erişim Tarihi: 28.10.2018).

Meade, James E. (1955). The Theory of Customs Unions. Amsterdam: North Holland Publishing.

MENRA (2017). Kür va Araz transsarhad çaylarında keçirilan monitorinqlarin naticalari (yanvar ayının III ongünlüyü üçün). Azərbaycan Respublikası Ekologiya və Təbii Sərvətlər Nazirliyi: http://eco.gov.az/az/xeberler/kurve-araz-transserhed-caylarinda-kecirilen-monitorinqlerin-neticeleri-yanvarayinin-iii-ongunluyu-ucun-7263 (Erişim Tarihi: 30.11.2018).

Michael, Louis G. (1938). Cotton Growing in the Soviet Union. Bureau of Agricultural Economics, Danube Basin District. Belgrade: United States Department of Agriculture.

Michel, Casey (2017). Why Uzbekistan's Shifts on Water Politics Matter. The Diplomat: https://thediplomat.com/2017/04/why-uzbekistans-shifts-on-water-politicsmatter/ (Erişim Tarihi: 31.07.2018).

Micklin, Philip (2016). “The future Aral Sea: hope and despair”. Environmental Earth Sciences 75 (9): 844.

Mollinga, Peter P. (2008). "Water, Politics and Development: Framing a Political Sociology of Water Resources Management”. Water Alternatives 1 (1): 7-23. 
Muradyan, Anna ve Kamal Ali (2013). Issues of the Kura-Araks River Basin: Now and Then. Epress.am: http://epress.am/en/2013/02/06/issues-of-the-kura-araksriver-basin-now-and-then.html (Erişim Tarihi: 18.02.2017).

Murphy, Joellyn (2014). “The Central Asian Power System: An Existing International Power Grid That's Still Missing an Integrative, Market-Based Trading Regime". Regional Energy Trade Workshop. http:/www.carecprogram.org/ uploads/events/2014/Regional-Energy-Trade-Workshop/PresentationMaterials/009_104_209_Session3-1.pdf (Erişim Tarihi: 18.11.2017).

Musayeva, Matanat (2013). "Inundations in the Kura River". International Journal of Business, Humanities and Technology 3 (3): 70-73.

Nepomilueva, Daria (2017). "Water scarcity indexes". Helsinki: Metropolia University of Applied Sciences. https://www.theseus.fi/bitstream/handle/10024/129346/ Nepomilueva_Daria.pdf?sequence=1 (Erişim Tarihi: 23.08.2018).

O'Hara, Sarah (2000). "Central Asia's water resources: contemporary and future management issues". International Journal of Water Resources Development 16 (3): 423-441.

Opitz, Petra (2015). Sustainable Energy Pathways in the South Caucasus: Opportunities for Development and Political Choices. Tiflis: South Caucasus Regional Office of the Heinrich Boell Foundation. https:/ge.boell.org/sites/default/files/ book_200x240mm.pdf (Erişim Tarihi: 29.10.2018).

Orhon, Kemal Berk (2015). Sinıraşan Yerüstü Suların Yönetiminde Dünya ve Türkiye Uygulamaları. Uzmanlık Tezi. Ankara: T.C. Orman ve Su İşleri Bakanlığı. http://suyonetimi.ormansu.gov.tr/Libraries/su/Kemal_Berk_Orhon Uzmanl\%C4\%B1k_Tezi_nihai.sflb.ashx (Erişim Tarihi: 23.02.2017).

Ögütçü, Mehmet (2015). "China in the South Caucasus: not a critical partnership but still needed". The South Caucasus Between integration and fragmentation. SAM ve European Policy Centre. 103-109. http://www.epc.eu/documents/ uploads/pub_5598_article_-_mehmet_ogutcu.pdf?doc_id=1639 (Erişim Tarihi: 25.09.2018).

Pak, Mariya \& Kai Wegerich (2014). "Competition and benefit sharing in the Ferghana Valley”. Central Asian Affairs 1: 225-246.

Pashayeva, Gulshan (2015). "Security challenges and conflict resolution efforts in the South Caucasus". The South Caucasus Between integration and fragmentation. SAM ve European Policy Centre. 37-44. http://www.epc.eu/documents/ uploads/pub_5598_article_-_gulshan_pashayeva.pdf?doc_id=1637 (Erişim Tarihi: 28.09.2018).

Paul, Amanda (2015). "The EU and the South Caucasus - Time for a stocktake". The South Caucasus Between integration and fragmentation. SAM ve European Policy Centre. 77-84. http://www.epc.eu/documents/uploads/ pub_5598_article_2_-_amanda_paul_-_eu.pdf?doc_id=1631 (Erişim Tarihi: 23.09.2018). 
Phys.org. (2018). Tajikistan says $\$ 4$ bn dam to open in November. Phys.org: https:// phys.org/news/2018-02-tajikistan-4bn-november.html (Erişim Tarihi: 20.08.2018).

Pierce, Richard vd. (2006). Beyond Gridlock: The Case for Greater Integration of Regional Electricity Markets. Ottawa: C.D. Howe Institute.

Pineau, Pierre-Olivier (2012). Integrating electricity sectors in Canada: Good for the environment and for the economy. Quebec: The Federal Idea. https:// ideefederale.ca/documents/Electricity_ang.pdf (Erişim Tarihi: 26.09.2018).

Pineau, Pierre-Olivier vd. (2004). "Measuring international electricity integration: a comparative study of the power systems under the Nordic Council, MERCOSUR, and NAFTA”. Energy Policy 32.

Pomfret, Richard (2009). "Regional integration in Central Asia". Economic Change and Restructuring 42 (1-2): 47-68.

Punsmann, Burcu Gültekin \& Anna Gevorgyan (2012). Review of Legal Issues between Armenia and Turkey. Ankara, Erivan: TEPAV.

Rakhimov, Mirzokhid (2010). "Internal and external dynamics of regional cooperation in Central Asia”. Journal of Eurasian Studies 1 (2): 95-101.

Rakhmatullaev, S. vd. (2017). "Water-Energy-Food-Environmental Nexus in Central Asia: From Transition to Transformation”. The Handbook of Environmental Chemistry. Eds. D. Barceló and A. Kostianoy. Berlin, Heidelberg: Springer. 1-18.

Rakhmatullaev, Shavkat vd. (2010). "Facts and Perspectives of Water Reservoirs in Central Asia: A Special Focus on Uzbekistan". Water 2 (2): 307-320.

Resmî Gazete (1975). (15288): s. 1. http://www.resmigazete.gov.tr/arsiv/15288.pdf (Erişim Tarihi: 15.07.2018).

Sakal, Halil Burak (2017). "A Quarter-Century Pursuit of Independence: Politics of Trade, Energy, and Economic Development in Uzbekistan”. Perceptions 22 (1): 49-90.

Salini Impreglio (2017). Rogun Hydropower Project. https://www.salini-impregilo. com/en/projects/in-progress/rogun-dam.html (Erişim Tarihi: 14.08.2018).

Schwind, Kathleen (2018). The Arpacay River: Cooperation and Water Sharing between Turkey and Armenia. https://www.slideshare.net/anselmocassiano/waterdiplomacy-by-kathleen-schwind-arpacay-river-turkey-vs-armenia (Erişim Tarihi: 24.07.2018).

Shiriyev, Zaur (2015). "NATO's South Caucasis paradigm: beyond 2014”. The South Caucasus Between integration and fragmentation. SAM ve European Policy Centre. 67-75. http://www.epc.eu/documents/uploads/pub_5598_article_-_ zaur_shiriyev.pdf?doc_id=1641 (Erişim Tarihi: 29.09.2018).

Small, Ian vd. (2003). "Safe water for the Aral Sea Area: could it get any worse?". European Journal of Public Health 13 (1): 87-89. 
Sojamo, Suvi (2008). "Illustrating co-existing conflict and cooperation in the Aral Sea Basin with TWINS approach". Central Asian Waters: Social, economic, environmental and governance puzzle. Eds. M. M. Rahaman and O. Varis. Espoo: Helsinki University of Technology. 75-88.

Sorbello, Paolo (2018). Uzbekistan Makes Up With Tajikistan Over Electricity. The Diplomat: https://hediplomat.com/2018/03/uzbekistan-makes-up-withtajikistan-over-electricity/ (Erişim Tarihi: 31.07.2018).

Spechler, Martin C. (2002). "Regional Cooperation in Central Asia”. Problems of PostCommunism 49 (6): $42-47$.

Spoor, Max \& Anatoly Krutov (2003). "The 'power of water' in a divided Central Asia”. Perspectives on Global Development and Technology 2 (3/4): 593-614.

Standardised Precipitation-Evapotranspiration Index (2016). SPEI Global Drought Monitor. SPEI: http://spei.csic.es/map/maps.html\#months=5\#month=11\#y ear=2016 (Erişim Tarihi: 10.07.2018).

Stucki, Virpi \& Suvi Sojamo (2014). "Nouns and numbers of the water-energysecurity nexus in Central Asia”. Water and Security in Central Asia: Solving a Rubik's Cube. Eds. V. Stucki vd. New York: Routledge. 5-24.

Suleymanov, Bahruz vd. (2008). "Hazardous Pollutant Database for Kura-Araks Water Quality Management". Transboundary Water Resources: A Foundation for Regional Stability in Central Asia. Eds. J. E. Moerlins vd. Dodrecht: Springer. 171-182.

Suleymanov, Bahruz vd. (2010). "Metals in Main Rivers of Azerbaijan: Influence of Transboundary Pollution”. Water Air Soil Pollution 213: 301-310.

Tanrisever, Oktay F. (2015). "The Eurasian Economic Union and the Caspian Sea Region". Geostrategic Maritime Review: The Caspian Sea - Geopolitical and Geostrategic Stakes for the Wider Region. Ed. Ellen Wasylina. Paris: IGMO. 44-64.

Tanrisever, Oktay F. ve Halil Burak Sakal (2017). Development of Hydropower Sector and its Impact on Energy-Environment Nexus in Central Asia. Almat1: ERI.

TEİAŞ (2017). Mevcut Enterkonneksiyon Hatlarının Net Transfer Kapasiteleri Duyurusu. https://www.teias.gov.tr/sites/default/files/2017-12/NetTransferK apasiteleri-29.12.2017.pdf (Erişim Tarihi: 19.09.2018).

The Tashkent Times (2018). Uzbekistan has ratified the Paris Climate Agreement. The Tashkent Times: http://tashkenttimes.uz/national/2949-uzbekistan-hasratified-the-paris-climate-agreement (Erişim Tarihi: 21.09.2018).

Turvey, Ralph (2006). "Interconnector Economics". Energy Policy 34.

Türkmenistan Dışişleri Bakanlığı (2018). The heads of states-founders International Fund for Saving the Aral Sea (IFAS) Summit was held. http://www.mfa.gov.tm/ en/articles/307 (Erişim Tarihi: 29.09.2018).

TürkPA (2016). TÜRKPA Çevre ve Doğal Kaynaklar Komisyonu Toplantısı 
Gerçekleştirildi. TURKPA: https://www.turk-pa.org/tr/archive/id2265 (Erişim Tarihi: 28.10.2018).

Ubilava, Mariam (2004). "Water Management in South Caucasus". Integrated Water Management of Transboundary Catchments: A Contribution from TRANSCAT. Venice. www.feem-web.it/transcat_conf/conf_papers/Ubilava.pdf (Erişim Tarihi: 20.11.2018).

UNDP (2014). Renewable Energy Snapshot: Tajikistan. http://www.undp.org/content/ dam/rbec/docs/Tajikistan.pdf (Erişim Tarihi: 29.09.2018).

UNDP/GEF (2007). Kura-Aras River Basin Transboundary Diagnostic Analysis. TDA report.

UNDP/GEF (2016). Small Hydropower Development: Global Challenges, National Problems and Solutions. GEF. http://www.eurasia.undp.org/content/dam/ rbec/docs/MGES\%20broshure\%20ENG.pdf (Erişim Tarihi: 29.09.2018).

Veldwisch, Geert Jan A. (2008). "Cotton, Rice \& Water: The Transformation of Agrarian Relations, Irrigation Technology and Water Distribution in Khorezm, Uzbekistan”. Bonn: Rheinischen Friedrich-Wilhelms-Universität zu Bonn. http://d-nb.info/993856918/34 (Erişim Tarihi: 19.09.2018).

Veldwisch, Gert Jan A. \& Peter P. Mollinga (2013). "Lost in Transition? The Introduction of Water Users Associations in Uzbekistan". Water International 38 (6): 758-773.

Veldwisch, Gert Jan \& Max Spoor (2008). “Contesting Rural Resources: Emerging 'Forms' of Agrarian Production in Uzbekistan'. The Journal of Peasant Studies 35 (3): 424-451.

Veliyev, Cavid (2015). "Turkey's role in the South Caucasus: between fragmentation and integration". The South Caucasus Between integration and fragmentation. SAM ve European Policy Centre. 85-93. http:/www.epc.eu/documents/ uploads/pub_5598_article_-_cavid_veliyev.pdf?doc_id=1633 (Erişim Tarihi: 19.09.2018).

Vener, Berrin Basak (2006). The Kura-Araks Basin: Obstacles and common objectives for an integrated water resources management model among Armenia, Azerbaijan, and Georgia. University of New Mexico, Water Resources Program, Albuquerque. http://repository.unm.edu/handle/1928/2591 (Erişim Tarihi: 24.03.2018).

Vener, Berrin Basak \& Michael E. Campana (2009). "Conflict and cooperation in the South Caucasus". Water, environmental security and sustainable rural development: conflict and cooperation in Central Eurasia. Eds. M. Arsel and M. Spoor. London: Routledge.

Viner, Jakob (1950). The Customs Union Issue. Washington, DC: Carnegie Endowment for International Peace.

Wegerich, Kai (2008). "Hydro-hegemony in the Amu Darya Basin". Water Policy 10 (Supplement 2): 71-88. 
Wegerich, Kai vd. (2007). "Reliving the past in a changed environment: Hydropower ambitions, opportunities and constraints in Tajikistan”. Energy Policy 35 (7): 3815-3825.

Whish-Wilson, Phillip (2002). "The Aral Sea environmental health crisis". Journal of Rural and Tropical Public Health 1: 29-34.

Wooden, Amanda E. (2014). "Kyrgyzstan's Dark Ages: Framing and the 2010 Hydroelectric Revolution”. Central Asian Survey 33 (4): 463-481.

World Bank (2001). Preserving the Northern Aral Sea in Kazakhstan: $\$ 64$ Million in IBRD Financing. The World Bank: http://www.worldbank.org/en/ results/2001/06/05/preserving-the-northern-aral-sea-in-kazakhstan-64million-in-ibrd-financing (Erişim Tarihi: 20.07.2018).

World Bank (2010). Load dispatch and system operation study in Central Asian power system. Madrid: World Bank. http:/documents.worldbank.org/ curated/en/961351468178154865/pdf/98830-WP-P117280-PUBLICBox393182B.pdf (Erişim Tarihi: 6.08.2018).

World Bank (2015). Study on strengthening the Central Asian Power Systems (CAPS) (English). Documents \& Reports: http://documents.worldbank.org/curated/ en/866191467998204221/Study-on-strengthening-the-Central-AsianPower-Systems-CAPS (Erişim Tarihi: 19.08.2018).

World Bank (2018). Databank. World Development Indicators: http://databank. worldbank.org (Erişim Tarihi: 19.08.2018).

World Energy Council (2007). Electricity in Central Asia: Market and Investment Opportunity Report. https:/www.worldenergy.org/wp-content/ uploads/2012/10/PUB_Asia_Regional_Report_Electricty_Market_And_ Investment_Opportunity_2007_WEC.pdf (Erişim Tarihi: 19.11.2016).

World Health Organization (2015). Proportion of population using improved drinkingwater sources. WHO: http://gamapserver.who.int/gho/interactive_charts/ mdg7/atlas.html?indicator=i2\&date=2015 (Erişim Tarihi: 22.07.2018).

Yu, Winston Cestti vd. (2014). Toward Integrated Water Resources Management in Armenia. Washington, DC: World Bank.

Zavgorodnyaya, Darya (2006). Water Users Associations in Uzbekistan: Theory and Practice. Göttingen: Cuvillier Verlag.

Zholdasova, Iliya (1997). "Sturgeons and the Aral Sea ecological catastrophe". Environmental Biology of Fishes 48: 373-380.

Zonn, Igor S. vd. (2009). The Aral Sea Encyclopedia. Berlin: Springer. 


\title{
Management of Transboundary Rivers: Regional Electricity Trade in the Aral and the Kura-Araks River Basins*
}

\author{
Halil Burak Sakal**
}

\begin{abstract}
Transboundary river basin management problems have been on top of the agenda of Central Asian politics, especially after the dissolution of the Soviet Union. This issue area has was given priority in the global political-environmental debates since the emergence of the Aral Sea problem during the Soviet era. In contrast, the environmental issues regarding the Kura-Araks river basin were relatively less discussed in the literature and thus have been paid less attention in the global political-environmental debates. This paper compares the environmental and economic issue areas of the water management and hydroelectricity generation in the Kura-Araks river basin and the Aral Sea basin and recommends solutions based on dyad-level regional electricity trade schemes based on regional cooperation models.
\end{abstract}

\section{Keywords}

Central Asia, Caucasus, Aral Sea basin, Kura-Araks river basin, transboundary water management, environment.

Date of Arrival: 08 August 2018 - Date of Acceptance: 30 January 2019

You can refer to this article as follows:

Sakal, Burak (2020). "Havza Yönetiminde Bölgesel Elektrik Ticareti Modeli: Aral ve Kura-Aras Havzaları Üzerine Bir Değerlendirme”. bilig - Journal of Social Sciences of the Turkic World 95: 241-270.

** Asst. Prof., Cappadocia University, Faculty of Economics and Administrative Sciences, Department of Political Science and International Relations - Nevsehir/Turkey

ORCID ID: 0000-0002-2054-5222

burak.sakal@kapadokya.edu.tr 


\title{
Управление трансграничными реками: анализ бассейнов Арала и Куры- Аракса*
}

\author{
Халиль Бурак Сакал
}

\begin{abstract}
Аннотация
Проблемы управления бассейнами трансграничных рек были в центре внимания политики Центральной Азии, особенно после распада Советского Союза. Этой проблемной области уделялось приоритетное внимание в глобальных политикоэкологических дебатах с момента возникновения проблемы Аральского моря в советское время. Напротив, экологические вопросы, касающиеся бассейна рек Кура-Аракс, относительно менее обсуждались в литературе и, следовательно, им уделялось меньше внимания в глобальных политико-экологических дебатах. В данной статье сравниваются экологические и экономические проблемы управления водными ресурсами и производства гидроэлектроэнергии в речном бассейне Кура-Аракс и бассейне Аральского моря и рекомендуются решения, основанные на двухуровневых схемах региональной торговли электроэнергией на основе моделей регионального сотрудничества.
\end{abstract}

\section{Ключевые слова}

Центральная Азия, Кавказ, бассейн Аральского моря, бассейн реки Кура-Аракс, управление трансграничными водами, окружающая среда.

\footnotetext{
Поступило в редакцию: 08 августа 2018 г. - Принято в номер: 30 января 2019 г. Ссылка на статью:

Sakal, Burak (2020). "Havza Yönetiminde Bölgesel Elektrik Ticareti Modeli: Aral ve Kura-Aras Havzaları Üzerine Bir Değerlendirme". bilig - Журнал Гуманитарныхх Наук Тюркского Мира 95: 241-270.

** Д-р, преподаватель, Университет Каппадокии, кафедра политических наук и междунардных отношений - Невшехир / Турция ORCID ID: 0000-0002-2054-5222 burak.sakal@kapadokya.edu.tr
} 